\title{
Epstein-Barr Nuclear Antigen 2
}

National Cancer Institute

\section{Source}

National Cancer Institute. Epstein-Barr Nuclear Antigen 2. NCI Thesaurus. Code C104664.

Epstein-Barr nuclear antigen 2 (487 aa, $\sim 55 \mathrm{kDa}$ ) is encoded by the Epstein-Barr virus EBNA2 gene. This protein is involved in the activation of host B-cells. 